Olga Cielemęcka

Uniwersytet Warszawski

\title{
Czas feminizmu
}

\begin{abstract}
C iorgio Agamben w wykładzie inauguracyjnym wygłoszonym na Wydziale USztuki i Projektowania Uniwersytetu Iuav w Wenecji postawił następujące pytanie: „co znaczy być współczesnym?”. Wskazawszy na trudności, które to pytanie niesie - wszakże teraźniejszość jest tym, co stale wymyka się nam z rąk, tym, co, paradoksalnie, jest zawsze niewczesne - filozof odpowiada, że:
\end{abstract}

Być współczesnym oznacza postrzegać w mroku teraźniejszości owo światło, które usiłuje do nas dotrzeć i nie może. Dlatego współcześni rzadko się zdarzają. I dlatego być współczesnym jest przede wszystkim sprawą odwagi, znaczy bowiem umieć nie tylko wpatrywać się uporczywie w mrok epoki, lecz także postrzegać w mroku skierowane ku nam światło. Albo też: stawiać się na spotkanie, do którego nigdy nie dojdzie

Przedmiotem tego artykułu będzie związek feminizmu i współczesności. Postawię pytanie o to, jaki kształt (albo raczej: wielorakie kształty) przybierać może współczesna myśl feministyczna w kontekście nie tylko przeobrażeń samego ruchu feministycznego, wyłonienia się tzw. trzeciej fali feminizmu, ale także mutacji koncepcji podmiotu na gruncie filozofii i w obliczu transformacji rzeczywistości społecznej. W szczególności zaś interesować mnie będzie problem zarysowany przez Giorgio Agambena: na ile, zamiast wpatrywać się w „mroki epoki”, feminizm zachowuje swoją płodną zdolność do tworzenia ożywczych utopii? Na ile potrafi jeszcze patrzeć ku światłu, które obiecuje zmianę i tę przyszłą zmianę artykułować?

\section{Czas kobiet}

W artykule z 1979 roku zatytułowanym Le temps des femmes Julia Kristeva zaproponowała podział na trzy ,generacje” w obrębie feminizmu. Pierwsze pokolenie walczyło o równość kobiet i mężczyzn pod hasłami równej płacy za równą pracę, domagało się możliwości zawodowego realizowania się

${ }^{1}$ Giorgio Agamben, Czym jest wspótczesność?, [w:] idem, Nagość, przeł. Krzysztof Żaboklicki, Wydawnictwo W.A.B., Warszawa 2010, s. 20. 
kobiet, dostępu do stanowisk i reprezentacji politycznej. Tendencję tę charakteryzowały dążenia uniwersalistyczne: zakładano, że kobiety wszędzie na świecie łączyło pewne wspólne doświadczenie opresji i dominacji, które stawało się ich udziałem, ponieważ były kobietami. Założenie tej wspólnoty losu przekuto na słynne hasło wyrażające solidarność kobiet: „Sisterhood is global" - siostrzeństwo jest globalne. Jednocześnie, na co przenikliwie zwraca uwagę Kristeva, feminizm ten był związany z życiem danego narodu, był głęboko zakorzeniony w jego społecznej i politycznej rzeczywistości, którą starał się transformować. Niekiedy hasła równościowe szły w parze z negacją „kobiecości” i deprecjacją macierzyńskiego doświadczenia, uznanymi za przeszkodę na drodze kobiet do zajęcia bardziej znaczącego miejsca w społeczeństwie, polityce, na rynku pracy. Całą tę formację Kristeva umieszcza w obszarze „logiki identyfikacji”, ponieważ wyróżnione tu pokolenie zasadniczo utożsamiało się z pewnym zbiorem dominujących wartości, nie tyle ideologicznych, z którymi podjęło walkę, ale raczej z obowiązującą racjonalnością państwa-narodu ${ }^{2}$.

Druga generacja, która wyłania się, zdaniem myślicielki, po wydarzeniach Maja 1968, w centrum swoich rozważań umieszcza pojęcie różnicy. Pyta więc o to, czym jest kobiecość, na czym polega specyfika kobiecej psychiki i ciała i jakie są ich symboliczne realizacje, a pytania te znajdują odzwierciedlenie w poszukiwaniu języka, także języka sztuki i stylu pisarskiego, który pozwoliłby oddać głos różnicy seksualnej - który pozwoliłby jej mówić tam, gdzie wcześniej była trwale przemilczana ${ }^{3}$. Wskazuje się tu na odmienność kobiecej cielesności, doświadczenia i pragnienia, które są mnogie i nie-tożsame ze sobą, a w konsekwencji inna-kobieta przeciwstawiona zostaje tradycyjnej, męskiej logice wykluczenia. Jak zauważa Kristeva, wraz ze zwrotem ku pojęciu różnicy nie tylko nowe, bardziej subtelne kwestie znalazły się w orbicie feministycznego zainteresowania, ale samo pojęcie czasu - któremu wszelkie pytania o periodyzację, o logikę zmiany pokoleniowej, próby wyróżnienia następujących po sobie, i konfrontujących się z poprzedzającymi je, generacji nieodłącznie towarzyszą - ulega przeformułowaniu. Teraz feministki ustawiają się poza logiką czasu linearnego, który wyznaczał rytm walki pierwszej generacji feministycznych aktywistek. Tym samym, generacja ta sytuuje swą refleksję w obrębie czasu archaicznego, czasu rekonstruowanej pamięci, z której czerpie i w którą wprojektowuje swoje mity, oraz czasu cyklicznego - czasowości marginesów, nigdy niewłączonych do głównego biegu wydarzeń4

${ }^{2}$ Julia Kristeva, Women's Time, trans. Alice Jardine, Harry Blake, „Signs” Autumn 1981, vol. 7, no. 1, s. 18-20.

3 Ibidem.

4 Zob.: Ibidem, s. 19-20. 
Nadejście trzeciej generacji Kristeva dopiero zapowiada. Zdaniem filozofki w jej ramach pojęcie różnicy zostanie przeobrażone, osłabione i przemieszczone z pola walk społecznych i politycznych oraz z obszaru badań nauk, takich jak biologia, na grunt metafizyki. Dzięki temu samo pojęcie tożsamości zostaje rozbite. Różnica zagnieżdża się tym razem w samym sercu podmiotowości, nie oddziela ona odtąd wnętrza od zewnętrza, ale wytwarza nowy obszar, nowe miejsce, w którym mnogie różnice przebiegają zawsze wewnątrz każdego podmiotu, „tożsamości” czy płci. W konsekwencji, feminizm trzeciego pokolenia odrzuca przekonanie o wyższości którejkolwiek płci (kobiecej czy męskiej) i jej jednorodnym charakterze i stopniowo zbliża się do odrzucenia wszelkich form antropomorfizmu.

Artykuł Kristevej próbuje określić pewną przyszłą formę feminizmu. Z dzisiejszej perspektywy możemy powiedzieć, że przynajmniej w pewnych swoich aspektach feminizm podjął refleksję, której zakres przewidywała francuska myślicielka. W centrum dzisiejszego myślenia feministycznego, jak słusznie przepowiedziała filozofka, sytuuje się zinternalizowana różnica. Już nie: my versus oni, kobiety versus mężczyźni, kultura wygrywana przeciw naturze, dom przeciw agorze, ale wewnętrznie podzielony podmiot staje się centralnym zagadnieniem. Warto dodać, że, zdaniem Kristevej, kolejna generacja nie porzuca zupełnie problemów i metod, którymi posługiwała się poprzednia, wszystkie one, do pewnego stopnia, współegzystują. To, co dziś określamy efemerycznym mianem „trzeciej fali”, może bardziej niż jej poprzedniczki, musi się mierzyć nie tylko z wyzwaniami, jakie przynosi współczesny świat, ale także z dziedzictwem, z którego wyrasta i stara się formułować pytania o przyszłe formy feministycznego „stawania się”.

Zatrzymajmy się jednak na chwilę nad samą kategorią, przy użyciu której przyjęło się periodyzować feminizm: nad tym, czym jest fala. Pierwszą falą określamy początki ruchu emancypacyjnego kobiet, walkę o prawa wyborcze; drugą - feminizm lat sześćdziesiątych i siedemdziesiątych z jego walką o polityczne wkluczenie kobiet, przyznanie im równych szans i praw takich, jakimi cieszyli się mężczyźni. Trzecia fala zaczęła się w latach dziewięćdziesiątych ubiegłego stulecia, jej specyfika jest trudno uchwytna, a jej dookreślenie sprawia wiele kłopotów tym, którzy przywiązani są do porządkujących podziałów czasowych. Powiedzieć można, że trzecia fala wyrasta w kontrze do backlashu ${ }^{5}$ lat osiemdziesiątych i rozpoznaje wyczerpanie formuły i strategii feminizmu drugofalowego. Ujmowanie czasu poprzez

5 Backlash to konserwatywny sprzeciw wobec feminizmu; niechęć i opór wobec feminizmu. Zob.: Susan Faludi, Backlash: the Undeclared War Against American Women, Doubleday, New York 1991. [Właśnie ukazało się polskie tłumaczenie książki Susan Faludi, która wprowadziła to określenie w tym węższym sensie do genderowego słownika: Susan Faludi, Reakcja. Niewypowiedziana wojna przeciw kobietom, przeł. Anna Dzierzgowska, Czarna Owca, Warszawa 2013 - przypis redaktorek.] 
pojęcie fal jest jednak kontrowersyjne, ponieważ ma ono także swój wymiar przestrzenny, czy może raczej: topograficzny. O ile jest to pojęcie pomocne w porządkowaniu historii ruchu feministycznego w Stanach Zjednoczonych, o tyle niekoniecznie adekwatnie opisuje ono walki o wyzwolenie kobiet w innych rejonach świata, stając się narzędziem imperializmu kulturowego, narzucającym model dynamiki feministycznej aktywności i kształt refleksji poza obszarem Stanów Zjednoczonych. Czy znajdujemy się teraz w okresie trzeciej fali, a może już czwartej? Czy z perspektywy polskiej feministki (albo tureckiej lub chińskiej) możemy po prawdzie powiedzieć, że złapałyśmy którąkolwiek z nich? Być może płyniemy pod prąd, a żadna fala nie ułatwia nam tego zadania?

Rzecz wydaje się w tym miejscu trudna do rozstrzygnięcia i choć trudność tę trzeba mieć na uwadze, pojęcie „trzeciej fali” może nam być pomocne w określeniu nowych wyzwań i nowych problemów, które współcześnie są rozważane na gruncie feminizmu.

\section{Nowoczesny projekt w ponowoczesnym świecie}

Dwa wstępne założenia, które charakteryzowały feminizm drugiej fali zostają współcześnie podważone. Po pierwsze, przekonanie o istnieniu jakiejś cechy czy doświadczenia, które byłoby właściwe wszystkim kobietom i tylko im. Przekonanie to zostało, co prawda, podważone już wcześniej: kobiety kolorowe, lesbijki, feministki z tzw. Trzeciego Świata już dawno zdemaskowały uzurpację dokonywaną przez białe, wykształcone Amerykanki, które, chcąc mówić w imieniu wszystkich kobiet, pomijają znaczące różnice między nimi. Tym razem chodzi jednak o to, by w miejsce zbiorowego podmiotu (kobiety czy feministki) nie podstawiać innych (lesbijki, czarne feministki itd.), a raczej uznać wielość tożsamości, splot rozlicznych funkcji i cech, wielorakie uwikłania, które charakteryzują każdy indywidualny podmiot. Dominującym stało się więc podejście intersekcjonalne, które podkreśla wagę różnych zmiennych: przynależności klasowej, rasowej, etnicznej, religijnej, orientacji seksualnej itd., i nie wyróżnia spośród nich nadrzędnej. W miejscu zunifikowanego podmiotu kobiecego staje wielość zróżnicowanych i ucieleśnionych podmiotowych figuracji.

Po drugie, w obrębie współczesnego feminizmu toczą się negocjacje z feministycznym dziedzictwem o to, co należałoby z niego zachować, a co porzucić. Nieaktualne wydają się rozpoznania zawarte w słynnym tekście The Madwoman in the Attic Sandry Gilbert i Susan Gubar, jeśli chcieć by je odnieść do współczesnych kobiet. Autorki dowodziły w nim, że opisany 
przez Harolda Blooma „lęk przed wpływem” ", będący kołem zamachowym męskiej twórczości, w której mężczyźni muszą się mierzyć ze swoimi wielkimi poprzednikami-ojcami, nie odnosi się do kobiet7. O ile mężczyźni muszą „zabić ojca”, by móc stać się oryginalnymi twórcami, o tyle kobiety potrzebują właśnie prekursorek, całej tej brakującej, nieobecnej tradycji kobiecego tworzenia. Dziś twórczy spór z poprzedniczkami wydaje się konieczny, by feminizm mógł się przeobrażać i adresować problemy, które wyłaniają się tak w nowej rzeczywistości polityczno-ekonomiczno-społecznej, jak i w wymiarze teoretycznym. Trzecią falę można nazwać feminizmem córek, które nie chcą być siostrami swoich matek ${ }^{8}$ - poszukują nowych, własnych formuł feminizmu, które odpowiadałyby ich doświadczeniom i czasom. Agnieszka Graff pisze o tej formacji:

Weterankom drugiej fali często wydaje się, że ich ruch zanikł - młode feministki odpowiadają im, że trzeba wiedzieć, gdzie szukać. Trzeciej fali więcej jest w internecie niż na ulicach. W kulturze niż w polityce. Jest płynna - przenika do innych ruchów społecznych. I jest zafascynowana mediami, muzyką, popkulturą. [...] Nowy feminizm jest barwny (często z przewagą akcentów różowych) i autoironiczny9.

Fascynacja popkulturą i internetem idą tu w parze ze społecznym aktywizmem, gloryfikacja dziewczyńskości zaś ze społecznym zaangażowaniem.

Zdobycze feminizmu, przynajmniej w krajach rozwiniętych, są faktem. Postulat równouprawnienia kobiet i mężczyzn z emancypacyjnego marzenia stał się oczywistością. Nawet najbardziej trwałe residuua patriarchalnej władzy, jak instytucja rodziny, ulegają demokratycznemu przeobrażeniu. Kobiet sukcesu, robiących karierę w polityce i biznesie, zajmujących najwyższe stanowiska, wciąż jest mniej niż mężczyzn cieszących się podobnym statusem, jednak jest ich wystarczająco wiele, by móc zapytać, czy ich indywidualny sukces jakkolwiek przyczynia się do poprawy położenia kobiet nieuprzywilejowanych i do walki z nierównościami społecznymi. Jednocześnie feminizm uległ instytucjonalizacji, został włączony i zakorzenił się w Akademii i jako jedna z dyscyplin uniwersyteckich dość bezboleśnie odnalazł się w ramach zasad kapitalizmu kognitywnego. Wszystkie te przemiany

${ }^{6}$ Zob.: Harold Bloom, Lęk przed wptywem, przeł. Agata Bielik-Robson, Marcin Szuster, UNIVERSITAS, Kraków 2002.

7 Zob.: Sandra M. Gilbert, Susan Gubar, The Madwoman in the Attic: The Woman Writer and the Nineteenth-Century Literary Imagination, Yale University Press, New Haven 2000.

${ }^{8}$ Nawiązuję tu do tytułu książki Astrid Henry Not My Mother's Sister: Generational Conflict and Third-Wave Feminism (Indiana University Press, Bloomington, Indiana 2004).

${ }^{9}$ Agnieszka Graff, Trzecia fala feminizmu, „Wysokie Obcasy” dodatek do „Gazety Wyborczej” 21 maja 2005; dostępne przez: http://www.wysokieobcasy.pl/wysokie-obcasy/1,53581,2715339.html (18.07.2013). 
podkopują starą wiarę w, po pierwsze, istnienie szczególnego rodzaju opresji, której podlegają wszystkie kobiety, po drugie zaś, w kumulatywny charakter emancypacyjnego postępu. Jednocześnie, jak pokazują Gillian Howie i Ashley Tauchert w artykule Feminist Dissonance: The Logic of Late Feminism, zjawiska te przyczyniają się do de-radykalizacji feminizmu ${ }^{10}$.

Howie i Tauchert twierdzą, że feminizm jest z gruntu nowoczesnym projektem w ponowoczesnym świecie ${ }^{11}$. Musi on reagować na coraz mniej uchwytne i jednolite fenomeny społeczne i na zmianę modelu władzy, która jest zarazem rozproszona i globalna, a jednocześnie nie stracić z oczu swojego celu: projektu wyzwolenia kobiet. Chciałabym zwrócić uwagę na dwa zjawiska, które wiążą się z reakcją feministycznych teoretyczek na wyzwania współczesności. W pierwszej kolejności, rozpoznają one biopolityczny charakter władzy, po drugie zaś, modyfikują sposoby myślenia o kategorii podmiotu wobec przeobrażenia tradycji humanistycznej w antyantropocentryczny posthumanizm.

\section{Rzeczywistość biopolityczna}

Sięgam po kategorię biopolityki, ponieważ przy jej użyciu można opisać podmiot jako zawsze już umiejscowiony w pewnej sieci władzy, która go determinuje. Podmiotowa pozycja nie jest wyznaczana przez jakąś jedną, główną zmienną, ale sytuuje się zawsze na przecięciu różnych sił i zjawisk, we wnętrzu technologicznych, medycznych, informatycznych i ekonomicznych sieci, które podmiot otaczają i określają. Pojęciem biowładzy francuski filozof Michel Foucault określił nowy paradygmat władzy; władza przypomina tu gęstą sieć, pozbawioną centrum. Jednocześnie każda pozycja czy relacja jest zawsze $\mathrm{z}$ władzą związana. W związku z tym podmiotowość jest tym, co wytwarzane przez władzę, która zakorzenia się w samym jej sercu i ciele. Antonio Negri i Michel Hardt starają się uwspółcześnić rozpoznania Foucaulta i przyglądają się różnorodnym aspektom i zjawiskom dzisiejszego porządku władzy. Swoje teorie rozwijają oni w trylogii, na którą składa się Imperium (2000, wydanie polskie: 2005), Multitude. War and Democracy in the Age of Empire (2004) oraz Rzecz-pospolita (2009, wydanie polskie: 2012) ${ }^{12}$. Zwróćmy uwagę na niektóre z charakterystyk współczesności wyróżnionych przez myślicieli.

${ }_{10}$ Zob.: Gillian Howie, Ashley Tauchert, Feminist Dissonance: The Logic of Late Feminism, [w:] eds. Stacy Gillis, Gillian Howie, Rebecca Munford, Third Wave Feminism. A Critical Exploration, Palgrave Macmillan, Basingstoke 2004, s. 37-48.

${ }^{11}$ Ibidem, s. 43.

${ }^{12}$ O możliwości rozwinięcia koncepcji Antonio Negriego i Michaela Hardta na użytek teorii feministycznej oraz o jej ograniczeniach zobacz artykuł Ewy Majewskiej Potwory. 
Negri i Hardt mówią o końcu epoki imperialistycznej, w której nieliczne państwa narodowe rozciągały swoją władzę na pozostałe terytoria, ustanawiając model władzy hierarchicznej, w której centrum włada peryferiami, starając się jednocześnie zachować swoją własną narodową tożsamość. $\mathrm{W}$ miejsce tego modelu nastaje, zdaniem autorów, Imperium. Imperium jest paradygmatem władzy, który wyłania się, gdy podziały terytorialne ulegają zamazaniu. Żadne państwo nie pełni już roli hegemona, ustalającego porządek globalny. Podział na tzw. Pierwszy, Drugi i Trzeci Świat załamuje się wobec rozpadu krajów komunistycznych, dekolonizacji oraz rosnącego rozwarstwienia społecznego. W krajach wysokorozwiniętych nie brak biedoty i nowego miejskiego proletariatu, zwanego prekariatem ${ }^{13}$, a w krajach ubogich bogactwo elit jest jeszcze bardziej rażące wobec ubóstwa, jakie cierpi reszta społeczeństwa. Zjawiska takie jak feminizacja pracy, które oznacza, że cechy charakterystyczne dla pracy kobiet, a więc niestabilność, ograniczenie świadczeń, niskie wynagrodzenia, rozmycie granicy między czasem wolnym a czasem pracy, dobitnie pokazują, że coraz więcej kobiet i mężczyzn żyje w warunkach niepewności, zmiany, rozsypującego się porządku. Ich życie staje się coraz mniej przewidywalne. Zmiany te wyznaczają życiową perspektywę współczesnych kobiet.

Feministki trzeciej fali nie mogą pominąć kwestii nierówności ekonomicznych i społecznych, realiów życia wyznaczonych przez doświadczenie kryzysu ekonomicznego, ale także faktu dojścia do głosu, wraz z dekolonizacją, kobiet z tzw. Trzeciego Świata, które domagają się zniesienia monopolu feministek z krajów wysokorozwiniętych na formułowanie postulatów i strategii walki o prawa kobiet. Jak podkreśla Margrit Shildrick: „feminizm trzeciej fali jest zawsze żywotnie zainteresowany etyką nakierowaną na innego, kimkolwiek by on nie był. Figura «kobiety», wokół której koncentrowała się uwaga feminizmu drugiej fali, staje się tylko jednym z pośród wielu wyznaczników, pośród wielu różnych znaczących różnic"14. Różnice ekono-

Próba feministycznej lektury Rzeczy-pospolitej Hardta i Negriego („Praktyka Teoretyczna” 2011, nr 4, s. 103-112).

${ }^{13}$ Prekarność - kondycja życia i pracy charakterystyczna dla późnego kapitalizmu. Odznacza się niestabilnością form zatrudnienia wynikającą z uelastycznienia warunków pracy i towarzyszącym temu stanem niepewności i lęku przed pogorszeniem sytuacji życiowej. Zob.: hasło „Prekarność” w Stowniku pojęć opracowanym przez Mikołaja Ratajczaka i Jana Sowę ([w:] Michael Hardt, Antonio Negri, Rzecz-pospolita. Poza własność prywatna i dobro publiczne, tłum. zbior., Praktyka Teoretyczna, Kraków 2012, s. 517-518) i Jan Sowa, Prekariat - globalny proletariat w epoce pracy niematerialnej, [w:] red. Joanna Sokołowska, Robotnicy opuszczają miejsca pracy, Muzeum Sztuki w Łodzi, Łódź 2010, s. 100-132.

${ }^{14}$ Margrit Shildrick, Introduction: Sex and Gender, [w:] eds. Stacy Gillis, Gillian Howie, Rebecca Munford, Third Wave Feminism. A Critical Exploration, Palgrave Macmillan, Basingstoke 2004, s. 69. Tam, gdzie nie zaznaczono inaczej, cytaty ze źródeł obcojęzycznych podaję w tłumaczeniu własnym. 
miczne, społeczne i etniczne oraz odmienne życiowe doświadczenia kobiet skutkują pluralizacją celów i postaw w obrębie ruchu. Z pozoru prowadzi to do osłabienia kategorii „kobiet” jako spójnego podmiotu politycznego. Zamiast tego, co wspólne wszystkim kobietom, jakiejś istoty kobiecości, feminizm trzeciofalowy poszukuje punktów zaczepnych; ledwie podobieństw rodzinnych między kobietami. W miejsce wspólnoty interesów dąży do chwilowych aliansów, zamiast globalnego siostrzeństwa proponuje strategie mikropolityki ${ }^{15}$.

Patricia S. Mann argumentuje, że na gruncie feminizmu należy stworzyć nową siatkę pojęciową, która nie będzie się już opierała na monolitycznym podmiocie politycznym przeciwstawionym, równie jednolitej, władzy patriarchalnej. Potrzeba nowych strategii zdolnych do „wyjaśnienia najbardziej palących problemów naszych czasów"16. Mann proponuje więc teorię sprawczości podmiotowej, w której jednostki są „zaangażowan[e] w konkretnie umiejscowione walki o kwestie rasy, klasy, seksualnych preferencji, jak i gender" ${ }^{17}$. Nacisk zostaje więc przeniesiony z kwestii tożsamościowych, na wspólne działanie. Podejście to, poprzez umiejscowienie i ucieleśnienie działających podmiotów, „podkreśla, jak istotne jest zwracanie uwagi na historyczną wypadkowość współdziałania wielu wymiarów ucisku i sprawczości w konkretnym instytucjonalnym kontekście"18.

Imperium, jako nowa forma światowego porządku, jest globalne i zdecentralizowane. Globalizacji towarzyszy zaś postępująca informatyzacja i technicyzacja; w oparciu o wysokie technologie pojawiają się nowe sieci komunikacji. Tendencje te znajdują swoje odzwierciedlenie w języku feministycznej refleksji. Prosty model władzy, w której opresja i panowanie sytuują się po jednej stronie, to znaczy po stronie patriarchatu, po stronie męskiej dominacji, zostaje zastąpiony Foucaultowską z ducha refleksją nad władzą jako siecią zależności i nad uwikłaniem w nią każdego podmiotu. Zdaniem Negriego i Hardta, cechą Imperium jest to, że jest ono całkowicie immanentne, co oznacza, że nie istnieje żadne „na zewnątrz” władzy, pozycja nieuwikłana czy niezaangażowana. Zrewidowane zostaje założenie, bardzo częste w teorii feministycznej, że myślenie opiera się na hierarchicznych przeciwieństwach, takich jak centrum-margines, mężczyzna-kobieta, naturakultura itd., w których człon kojarzony z tym, co kobiece zostaje nacechowany

${ }_{15}$ Zob.: Patricia S. Mann, Micro-Politics: Agency in a Post-Feminist Era, University of Minnesota Press, Minneapolis 1994.

${ }^{16}$ Ibidem, s. 1.

17 Rebecca Johnson, Gender, rasa, klasa i seksualna orientacja. Teoretyczne ujęcia intersekcjonalności, przeł. Ewa Charkiewicz, Biblioteka Online Think Tanku Feministycznego 2009 [2005]; dostępne przez: http://www.ekologiasztuka.pl/pdf/foo68johnson.pdf (15.02.2013), s. 10 .

${ }^{18}$ Ibidem. 
negatywnie. Podziały te zostały dość skutecznie zdekonstruowane, Negri i Hardt nazywają je wprost anachronicznymi, a Donna Haraway uważa, że zostały one „technowchłonięte” (techno-digested), przez co rozumie, że rozwój technologii pozwolił przekroczyć i zatrzeć dawne binaryzmy ${ }^{19}$. Ani żadne jądro władzy, na które można przerzucić całą winę, ani żadne dominujące, opresyjne metanarracje nie mogą zostać łatwo zidentyfikowane.

W konsekwencji, sam ruch feministyczny musi się stać bardziej samoświadomy i wyczulony na formy opresji, które także on sam może produkować. Wiąże się z tym rezygnacja z tonu moralnej wyższości i protekcjonalności, który zdarzało się przyjmować feministkom starszej generacji. Za przykład może posłużyć stosunek do kwestii pornografii i prostytucji. $\mathrm{W}$ latach osiemdziesiątych $\mathrm{XX}$ wieku toczono przeciwko nim zażarte boje. Wiele ważnych, ikonicznych figur w ruchu feministycznym (wśród nich Gloria Steinem, Catherine MacKinnon, Andrea Dworkin, Robin Morgan) jednoznacznie utożsamiało te zjawiska z uprzedmiotowieniem kobiet i nadużyciami w stosunku do nich. We współczesnych „wojnach seksualnych” coraz bardziej dochodzi do głosu stanowisko zwane sex-positive, w którym podkreśla się kwestię wolnego wyboru. Kobieta ma prawo dysponować swoim ciałem jak towarem, a pracownice (i pracownicy) branży usług seksualnych wykonują pracę taką, jak każda inna i nie powinny w związku z tym być stygmatyzowane.

Teorie inspirowane Foucaultowską kategorią biowładzy pozwalają dostrzec, że każda jednostka jest zawsze już usytuowana w obrębie złożonych sieci zależności, a jej pozycja ofiary może być także pozycją siły i sprawstwa. Negri i Hardt uzupełniają ten wątek rozważaniami nad twórczym, potencjalnie rewolucyjnym działaniem biopolitycznym. Jak zauważa Rebecca Johnson, zwrócenie uwagi przez ruchy feministyczne na różnorodne uwarunkowania pozycji kobiet w społeczeństwie przyczyniło się do odkrycia, że „na skrzyżowaniach powstają nie tylko konkretne formy wiktymizacji, ale także nowe strategie oporu" ${ }^{20}$. Owe skrzyżowania, o których tu mowa, to miejsca, gdzie przeplatają się ze sobą najróżniejsze zmienne, płeć i orientacja seksualna, pochodzenie społeczne i zamożność, rasa i narodowość, wiek i styl życia. Pewne ich konfiguracje powodują zwielokrotnienie form dyskryminacji i opresji, czynią podmiot bardziej narażonym na przemoc, ale z tych miejsc mogą także być wytwarzane nowe, innowacyjne strategie walki.

19 Zob.: Donna Haraway, Manifest cyborgów: Nauka, technologia i feminizm socjalistyczny lat osiemdziesiątych, przeł. Sławomir Królak, Ewa Majewska, „Przegląd Filozoficzno-Literacki” 2003, nr 1 (3), s. 49-87.

${ }^{20}$ Rebecca Johnson, op. cit., s. 8. 


\title{
Posthumanistyczny podmiot
}

Druga istotna kwestia, którą najnowsze teorie feministyczne biorą pod uwagę i na własne sposoby opracowują, dotyczy przeobrażeń w sposobie myślenia o podmiocie. Na gruncie humanistyki w drugiej połowie XX wieku pojawiła się tendencja do dekonstruowania i osłabiania podmiotu. Mówi się o podmiocie ujarzmionym, słabym czy płynnym, będącym efektem działania różnych sił, takich jak dyskurs, gry językowe czy władza, niezdolnym do działania, nieistotnym. Roland Barthes pisal Śmierć autora, Stowa i rzeczy stały się bestsellerem, powtarzano frazesy o śmierci człowieka, a Francis Fukuyama dowodzil, że historia już dobiegła końca. Z tego apokaliptycznego rozbuchania dworował sobie Jacques Derrida, gdy pisał:

\begin{abstract}
zaprawdę powiadam wam, to nie tylko koniec tego, lecz także i przede wszystkim tego tam, koniec historii, koniec walki klasowej, koniec filozofii, śmierć Boga, koniec religii, koniec chrześcijaństwa i moralności (to [ça] było największą naiwnością), koniec podmiotu, koniec człowieka, koniec Zachodu, koniec Edypa, koniec ziemi, Apocalypse Now, powiadam wam, w kataklizmie, ogniu, krwi, trzęsieniu ziemi, które wstrząsa fundamentami, napalmie zrzucanym z nieba przez helikoptery, to także koniec literatury, koniec malarstwa, sztuka jako rzecz przebrzmiała, koniec psychoanalizy, koniec uniwersytetu, koniec fallocentryzmu i fallogocentryzmu, i któż wie czego jeszcze? ${ }^{21}$
\end{abstract}

Rosi Braidotti, filozofka związana od wielu lat z Uniwersytetem w Utrechcie, zauważa, że pojawienie się tezy o śmierci człowieka zbiega się w czasie z dojściem do głosu grup ludzi, którzy wcześniej nie mieli takiej możliwości: kobiet, narodów skolonizowanych, mniejszości etnicznych i seksualnych. Idea kresu człowieka z punktu widzenia opresjonowanych jest czymś obcym. Dla nich doświadczenie fragmentaryzacji ,ja”, które zostaje tu odkryte, jest doświadczeniem podstawowym: aby „ogłosić śmierć człowieka - pisze myślicielka - trzeba najpierw nabyć prawo do mówienia jako podmiot; aby zdemistyfikować metadyskurs trzeba najpierw mieć dostęp do mowy"22. Braidotti demaskuje paradoksalne uczucie zawiści, które odczuwają w stosunku do kobiet mężczyźni-filozofowie, a reakcją na które jest ogłoszenie kryzysu nowoczesności i załamanie się wiary tak w system wartości, który jej towarzyszył, jak i w podmiotową sprawczość. Owa zawiść bierze się stąd, że kobiety, za sprawą doświadczenia opresji, mogą tak w teorii, jak w aktywizmie feministycznym, tworzyć nowe, płodne strategie oporu; są w centrum wiel-

${ }^{21}$ Jacques Derrida, Of an Apocalyptic Tone Newly Adopted in Philosophy, trans. John P. Leavy Jr, [w:] eds. Harold Coward, Toby Foshay, Derrida and Negative Theology, State University of New York Press, Albany 1992, s. 48.

${ }^{22}$ Rosi Braidotti, Podmioty nomadyczne. Ucieleśnienie i różnica seksualna $w$ feminizmie wspótczesnym, przeł. Aleksandra Derra, Wydawnictwa Akademickie i Profesjonalne, Warszawa 2009, s. 172. 
kiego fermentu idei, który transformuje zarówno rzeczywistość społeczną, jak i wstrząsa podstawami myślenia. Dlatego, pisze ironicznie Braidotti:

musi być niewygodne być męskim, białym, heteroseksualnym intelektualistą średniej klasy w takim momencie historii, w którym tyle mniejszości i opresjonowanych grup przemawia w swojej sprawie [...]. Ponieważ brakuje im [męskim intelektualistom O.C.] historycznego doświadczenia opresji ze względu na płeć, paradoksalnie brakuje im czegoś, czego nie mają ${ }^{23}$.

Mężczyźni, którzy dotąd byli monopolistami na rynku idei i teorii, nagle zdają sobie sprawę z tego, że w awangardzie są teraz kobiety. To refleksja nad tym, co inne, nad opresją i przemocą jest kluczem do przedefiniowania klasycznych pojęć, takich jak podmiotowość czy racjonalność, pozwala na rozumną krytykę rozumu ${ }^{24}$ i przemyślenie na nowo naszej współczesności. Braidotti zwraca uwagę na następujący problem, który wiąże się z postmodernistycznym rozbrojeniem podmiotu:

dekonstruowanie, odrzucenie czy wyeliminowanie pojęcia racjonalnego podmiotu w tym właśnie momencie historii, w którym kobiety zaczęły mieć dostęp do użycia dyskursu, siły i przyjemności, oraz jednoczesne popieranie „tego, co kobiece” czy „stawania się kobietą” dyskursu teoretycznego - kobietą jako figurą nowoczesności - wydaje mi się bardzo problematyczne ${ }^{25}$.

Pozbycie się podmiotu, sprowadzenie go do roli produktu ubocznego działania jakichś przekraczających go sił, oznacza zmarginalizowanie problemu ucieleśnienia, czy też upłciowienia, podmiotu.

Braidotti i inne feministyczne filozofki zdecydowanie nie godzą się na popadnięcie w ton nihilistyczny czy apokaliptyczny, nie pociąga ich piękna, postmodernistyczna katastrofa. Dla nich

nigdy nie było bardziej życiodajnej śmierci niż śmierć człowieka. Oznacza ona bowiem podniesienie się całej masy pseudo-podmiotów do roli Podmiotu. [...] W chwili, gdy problematyczne stało się nasze człowieczeństwo wszystkie obiekty zdolne do odczuwania, reprezentowania, pragnienia, aspirują dziś do roli podmiotów ${ }^{26}$.

Braidotti proponuje pojęcie podmiotu nomadycznego (zapożycza się tu u Gilles'a Deleuze'a i Félixa Guattariego) - to szczególnego rodzaju mit polityczny, który ma wyrażać „potencjał i ważność mitotwórczych wyobrażeń”,

${ }^{23}$ Ibidem, s. 169.

${ }^{24}$ Ibidem, s. 173.

${ }^{25}$ Ibidem, s. 171-172.

${ }^{26}$ Szymon Wróbel, Nicość. Śmierć. Relief; Internetowy Serwis Filozoficzny Diametros; dostępne przez: http://www.diametros.iphils.uj.edu.pl/?l=1\&p=deb5\&m=17\&ii=427 (02.02.2013). 
pozwalający na przekroczenie „politycznego i intelektualnego zastoju tych ponowoczesnych czasów"27. Figura ta ma obrazować otwarcie nowego pola do eksperymentowania, poszukiwania i pytania. Nomada wskazuje na otwartą przestrzeń, taką, którą można uformować, przeobrazić. Symbolizuje wielość dróg i przechodzenie między różnymi umiejscowieniami, praktykami i aspektami tożsamości. Nadrzędnym celem staje się stworzenie możliwości, by mówić o wielorakich, rożnie uwarunkowanych figuracjach kobiecej podmiotowości i je uprawomocnić. Nomadyczny projekt ma odnosić się zarówno do sfery politycznej, jak i prywatnej. Dotychczasowe sposoby reprezentacji kobiecości mogą być podważone i przeobrażone, a w ich miejscu wyłaniają się nowe sposoby mówienia i myślenia o kobietach. Kobieta jako podmiot polityczny może być bytem wewnętrznie sprzecznym. To samo odnosi się do indywidualnej tożsamości, do poziomu nieświadomości i pragnienia, gdzie niespójności nie trzeba eliminować, ale raczej afirmować ich złożoność i różnorodność. „Kobiecy podmiot feministyczny - pisze autorka - jest jednym z terminów procesualnych, którego nie wolno i nie można kształtować w liniową, teleologiczną formę podmiotowości, ale który powinno się traktować jako przecięcie podmiotowego pragnienia ze świadomą transformacją społeczną"28.

Nastaje więc nie tyle Czas Apokalipsy, co czas feminizmu, który może ożywić myśl i skłonić do działania. Feminizm to nie praktyka, pisze filozofka, ale „napęd twórczy”, „miejsce transformacji”, „ruch, który zmierza do zmiany życia”. Braidotti stara się przepracować wzajemne powiązania między ciągłym czasem historii a wewnętrznym czasem genealogii, o których pisała Julia Kristeva, tak, by móc wyjaśnić proces kobiecego s ta w a nia si ę podmiotem. Jej propozycja zakłada podmiot kobiecy, który jest procesualny, wielorako określony, wielowarstwowy, umiejscowiony w pewnym historycznym tu i teraz, ale zarazem zdolny do dookreślania się stale na nowo. Kobieca tożsamość odnosi się zarówno do historycznie uformowanego tworu zwanego „Kobietą”, ale także do „innej czasowości: głębszego i bardziej nieciągłego znaczenia czasu, który jest czasem transformacji, oporu, politycznych genealogii i stawania się"29.

Postkobieca czy postludzka rzeczywistość nie oznacza wyeliminowania ani kobiety, ani człowieka, wręcz przeciwnie, pozwala na dostrzeżenie ich $\mathrm{w}$ inny sposób: jako uwikłanych w świat. Ludzki podmiot jest bytem działającym, przekształcającym otaczającą go rzeczywistość, a zarazem bytem przez nią określonym. Punktem na chronologicznej linii czasu, ale zarazem tym, co wychylone ku przyszłości.

${ }^{27}$ Rosi Braidotti, op. cit., s. 28.

${ }^{28}$ Ibidem, s. 206.

${ }^{29}$ Ibidem, s. 199. 


\section{Utopia, czyli o czym marzą feministki}

„Feministki kochają utopie” ${ }^{0}$ twierdzi Sally L. Kitch w swojej pracy zatytułowanej Higher Ground. Jednak jaką utopię możemy jeszcze pokochać wobec demaskacji, i porzucenia, feministycznego mitu jedności, siostrzeństwa, jednorodnego kobiecego podmiotu politycznego, wspólnego celu? Kitch posądza wszystkie powyższe pojęcia, wzięte z feministycznego słownika, o utopijność. Posługując się nimi, feminizm zajmuje się produkowaniem hipostaz. Dążąc do wypracowania uniwersalnego podmiotu kobiecego, staje się on niezdolny do wyrażenia różnic między kobietami i pozostaje oderwany od materialnych warunków egzystencji konkretnych kobiet. Wedle autorki, podejście intersekcjonalne wyklucza się z myśleniem utopijnym, które, konstruując idealne światy w czasie future perfect, zapomina o pogmatwanej, pluralistycznej i z konieczności nieperfekcyjnej teraźniejszości. Słusznie, jak sądzę, Lise Shapiro Sanders stawia tu zarzut, że Kitch odrzuca wszystkie feministyczne utopie, krytykując tylko jeden szczególny ich rodzaj.

Utopię proponuję rozumieć inaczej niż zrobiła to amerykańska badaczka. Nie jako mity o jedności, lecz jako siłę napędową feminizmu, jego przyczynę celową - paradoksalną, bo pochodząca z przyszłości. Utopia to wymiar czasu, który pozwala łączyć marzenie, które umiejscowione jest w przyszłości z działaniem w konkretnym momencie historycznym i reagowaniem w danej rzeczywistości na zastany w niej stan rzeczy. Utopia nie może być stałym punktem, ale raczej zmieniającym się horyzontem, ponieważ „utopia jest [dla feminizmu - O.C.] przydatna tylko o tyle, o ile pozostaje zawsze otwarta, możliwa do oprotestowania, ciągle w sprzeczności z samą sobą" ${ }^{1}$. W zwielokrotnieniu kobiecych figuracji podmiotowych, poprzez uwzględnienie różnych elementów, które składają się na podmiot, w kobiecym wielogłosie, który może i przekształca się czasami w kakofonię, zostaje skonstruowany taki właśnie nietrwały, stale przekształcany i podatny na zmianę horyzont przyszłości.

\section{BIBLIOGRAFIA}

Agamben Giorgio, Czym jest wspótczesność?, [w:] idem, Nagość, przeł. Krzysztof Żaboklicki, Wydawnictwo W.A.B., Warszawa 2010.

${ }^{30}$ Sally L. Kitch, Higher Ground: From Utopianism to Realism in American Feminist Thought and Theory, The University of Chicago Press, Chicago 2000, s. 1.

${ }^{31}$ Lise Shapiro Sanders, 'Feminists Love a Utopia': Collaboration, Conflict, and the Future of Feminism, [w:] eds. Stacy Gillis, Gillian Howie, Rebecca Munford, Third Wave Feminism. A Critical Exploration, Palgrave Macmillan, Basingstoke 2004, s. 50. 
Bloom Harold, Lęk przed wpływem, przeł. Agata Bielik-Robson, Marcin Szuster, UNIVERSITAS, Kraków 2002.

Braidotti Rosi, Podmioty nomadyczne. Ucieleśnienie i różnica seksualna $w$ feminizmie wspótczesnym, przeł. Aleksandra Derra, Wydawnictwa Akademickie i Profesjonalne, Warszawa 2009.

Derrida Jacques, Of an Apocalyptic Tone Newly Adopted in Philosophy, trans. John P. Leavy Jr, [w:] eds. Harold Coward, Toby Foshay, Derrida and Negative Theology, State University of New York Press, Albany 1992.

Faludi Susan, Backlash: the Undeclared War Against American Women, Doubleday, New York 1991. [Wydanie Polskie: Susan Faludi, Reakcja. Niewypowiedziana wojna przeciw kobietom, przeł. Anna Dzierzgowska, Czarna Owca, Warszawa 2013].

Gilbert Sandra M., Susan Gubar, The Madwoman in the Attic: The Woman Writer and the Nineteenth-Century Literary Imagination, Yale University Press, New Haven 2000.

Graff Agnieszka, Trzecia fala feminizmu, „Wysokie Obcasy” dodatek do „Gazety Wyborczej” 21 maja 2005; dostępne przez: http://www.wysokieobcasy.pl/wysokie-obcasy/1,53581,2715339.html (18.07.2013).

Haraway Donna, Manifest cyborgów: Nauka, technologia i feminizm socjalistyczny lat osiemdziesiątych, przeł. Sławomir Królak, Ewa Majewska, „Przegląd Filozoficzno-Literacki” 2003, nr 1 (3).

Henry Astrid, Not My Mother's Sister: Generational Conflict and Third-Wave Feminism, Indiana University Press, Bloomington, Indiana 2004.

Howie Gillian, Ashley Tauchert, Feminist Dissonance: The Logic of Late Feminism, [w:] eds. Stacy Gillis, Gillian Howie, Rebecca Munford, Third Wave Feminism. A Critical Exploration, Palgrave Macmillan, Basingstoke 2004.

Johnson Rebecca, Gender, rasa, klasa i seksualna orientacja. Teoretyczne ujęcia intersekcjonalności, przeł. Ewa Charkiewicz, Biblioteka Online Think Tanku Feministycznego 2009 [2005]; dostępne przez: http://www.ekologiasztuka.pl/pdf/foo68johnson.pdf (15.02.2013).

Kitch Sally L., Higher Ground: From Utopianism to Realism in American Feminist Thought and Theory, The University of Chicago Press, Chicago 2000.

Kristeva Julia, Women's Time, trans. Alice Jardine, Harry Blake, „Signs” Autumn 1981, vol. 7, no. 1 .

Majewska Ewa, Potwory. Próba feministycznej lektury Rzeczy-pospolitej Hardta i Negriego, „Praktyka Teoretyczna” 2011, nr 4.

Mann Patricia S., Micro-Politics: Agency in a Post-Feminist Era, University of Minnesota Press, Minneapolis 1994.

Ratajczak Mikołaj, Jan Sowa, hasło „Prekarność”, [w:] Michael Hardt, Antonio Negri, Rzecz-pospolita. Poza własność prywatna i dobro publiczne, tłum. zbior., Praktyka Teoretyczna, Kraków 2012.

Sanders Lise Shapiro, 'Feminists Love a Utopia': Collaboration, Conflict, and the Future of Feminism, [w:] eds. Stacy Gillis, Gillian Howie, Rebecca Munford, Third Wave Feminism. A Critical Exploration, Palgrave Macmillan, Basingstoke 2004.

Shildrick Margrit, Introduction: Sex and Gender, [w:] eds. Stacy Gillis, Gillian Howie, Rebecca Munford, Third Wave Feminism. A Critical Exploration, Palgrave Macmillan, Basingstoke 2004.

Sowa Jan, Prekariat - globalny proletariat w epoce pracy niematerialnej, [w:] red. Joanna Sokołowska, Robotnicy opuszczaja miejsca pracy, Muzeum Sztuki w Łodzi, Łódź 2010.

Wróbel Szymon, Nicość. Śmierć. Relief; Internetowy Serwis Filozoficzny Diametros; dostępne przez: http://www.diametros.iphils.uj.edu.pl/?l=1\&p=deb5\&m=17\&ii=427 (02.02.2013). 